\title{
Ulcer Disease in the Excluded Segments after Roux-en-Y Gastric Bypass: a Current Review of the Literature
}

\author{
Gabriel Plitzko ${ }^{1} \cdot$ Grégoire Schmutz $^{1} \cdot$ Dino Kröll $^{1} \cdot$ Philipp C. Nett ${ }^{1} \cdot$ Yves Borbély $^{1}$ (D)
}

Received: 16 June 2020 / Revised: 10 November 2020 / Accepted: 11 November 2020 / Published online: 24 November 2020

(C) The Author(s) 2020

\begin{abstract}
Ulcer disease in excluded segments after Roux-Y gastric bypass (RYGB) is rare but can evolve into a life-threatening situation. The excluded segments exhibit a different behavior from that of non-altered anatomy; perforated ulcers do not result in pneumoperitoneum or free fluid, and therefore must be met with a low threshold for surgical exploration. The anatomical changes after RYGB impede routine access to the remnant stomach and duodenum. There are various options to address bleeding or perforated ulcers. While oversewing and drainage preserves the anatomy and forgoes resection, remnant gastrectomy offers a definitive solution. The importance of traditional risk factors such as smoking or use of non-steroidal anti-inflammatory drugs is unclear. Eradication of Helicobacter pylori and secondary prophylaxis with proton-pump inhibitors is advisable, albeit in double-dose.
\end{abstract}

Keywords Anti-inflammatory agents $\cdot$ Non-steroidal anti-inflammatory drugs $\cdot$ Roux-Y gastric bypass $\cdot$ Peptic ulcer perforation . Hemorrhage · Gastritis · Gastrostomy · Morbid obesity $\cdot$ Gastric remnant

\section{Introduction}

Bariatric surgery is the most effective treatment for morbid obesity and results in sustained weight loss and resolution of comorbidities. Over the past decades, the number of performed bariatric operations has been on a constant rise, reaching more than half a million procedures a year worldwide [1]. This number is expected to increase even further, as metabolic surgery is advocated as a treatment option for type 2 diabetes mellitus (T2DM) in patients with a body mass index (BMI) $<35 \mathrm{~kg} / \mathrm{m}^{2}$ [2].

Yves Borbély

yves.borbely@insel.ch

Gabriel Plitzko

gabriel.plitzko@gmail.com

Grégoire Schmutz

gregoire.schmutz88@gmail.com

Dino Kröll

dino.kroell@insel.ch

Philipp C. Nett

philipp.nett@insel.ch

1 Clinic for Visceral Surgery and Medicine, University Hospital Bern Inselspital, and University of Bern, Freiburgstrasse,

CH-3010 Bern, Switzerland
Roux-en-Y gastric bypass (RYGB) is one of the most commonly performed procedures, is seen by many as the gold standard treatment in patients with preexisting gastroesophageal reflux disease, and is suggested as the first-choice procedure for patients with T2DM [1]. After the creation of a small gastric pouch, food is diverted away from the stomach directly into the small bowel, and acid produced in the remnant stomach will no longer reach the esophagus anymore. These distinctive changes in anatomy are thought to be key factors for sustained weight loss. However, they also result in the downsides of this procedure, above all hindering access to the biliary tree, the remnant stomach, and the duodenum [3-5].

Apparent peptic ulcer disease (PUD) in the excluded stomach or duodenum is rare but leads to severe morbidity and can be life-threatening. The anatomical changes post-RYGB lead to a different clinical presentation in an altered pathophysiological environment [6]. Whereas there are extensive data on marginal ulceration (MU)-ulcers at the gastro-jejunal anastomosis - experience with ulceration in the excluded segments, especially in regard to treatment and prevention, is mostly limited to small series and case reports [6-28]. Therefore, this review aims to summarize the available data, to contrast existing guidelines to the altered situation post-RYGB and provide treatment recommendations. 


\section{Materials and Methods}

All studies reporting ulcer formation in the excluded segments of post-RYGB patients were considered eligible. A MEDLINE search was performed during May 2020. The search terms applied are listed in Table 1 . In addition, the reference list of articles retrieved by the search was assessed for further publications. Titles and abstracts of publications were screened by the primary author GP. Full texts of possibly relevant studies were evaluated to determine eligibility. All eligible articles were reviewed by the corresponding author YB and co-author PN. Consensus among authors was made regarding decisions to exclude articles. NonEnglish articles were also excluded. The PRISMA flow diagram is presented in Fig. 1 [29].

The following data were collected: age, sex, time since the bariatric procedure, potential risk factors (smoking behavior, NSAIDs, HP), clinical presentation, radiological findings, site of affection, treatment, outcome, and duration of follow-up.

\section{Incidence and Presentation}

The true incidence of PUD after RYGB is not known, and the reported cases are certainly biased towards complicated PUD, such as bleeding and perforation.

Here, we summarize reports of 54 patients in 5 case series and 18 case reports (tbl1, tbl2) [6-28]. Thirty-five (65\%) of these individuals were female with an age ranging from 21 to 74 years. The interval between surgery and the onset of symptoms varied between 2.5 months and 20 years (Table 2). Fifteen patients $(28 \%)$ presented with gastrointestinal bleeding, whereas 38 patients $(70 \%)$ had perforated ulcers. The site of bleeding was the gastric remnant in $53 \%$ and the duodenum in $47 \%$; $34 \%$ of perforations were localized in the gastric remnant and $66 \%$ were in the duodenum (Table 3). The leading symptom at presentation was epigastric or upper abdominal pain. In cases of bleeding, melena, weakness, and anemia were common findings. Patients with perforation presented with signs of sepsis, such as hypotonia, tachycardia, fever, and elevated leukocytes.

\section{Pathophysiological Considerations}

\section{Gastrin Levels and Acid Production in the Excluded Stomach}

After RYGB, there is continued, although diminished, basal, and stimulated acid excretion in the excluded stomach. Gastrin levels are decreased after RYGB, yet the gastric mucosa maintains its ability to respond to vagal and hormonal stimuli [30], thus preserving an acidic environment $[12,30-32]$. The amount of acid production is influenced by the proportion of the parietal cell mass, partitioned by surgery to the pouch and the distal stomach, a factor certainly influencing the development of MU [33-35]. In theory, high transection increases acid production in the excluded stomach and contributes to acid-related mucosal injury in the antrum and duodenum [12, 31]. Furthermore, post-RYGB, cellular hypertrophy of the gastric mucosa occurs in the presence of a reduction in $\mathrm{G}$ cells, again lowering gastrin production [36]. Additionally, in protonpump inhibitor (PPI)-treated mice with normal anatomy, the resulting hypochlorhydria causes bacterial overgrowth resulting in gastric inflammation [37].

\section{Buffering Effect of Nutrients}

After RYGB, there is no counteracting effect on the acid in the antrum and duodenum as the ingested food bypasses the excluded segments. However, the exclusion of the duodenum also leads to a reduced and desynchronized pancreatic secretion as the strongest stimulus of bicarbonate secretion is the duodenal presentation of nutrients. Furthermore, bile refluxing into the gastric remnant also contributes to mucosal injury $[12,21,38,31]$.

\section{Role of PPI}

In large database-driven studies, up to a quarter of postRYGB patients are on PPIs [39, 40]. There is an interplay between PPI intake and gastrin levels, and longterm use leads to hypergastrinemia stimulated by a reduction in gastric acid secretion via somatostatin

Table 1 Search terms and retrieved results

\begin{tabular}{llll}
\hline Search set & Terms & & \\
\hline$\# 1$ & "gastric bypass"[Title/Abstract] AND ulcer[Title/Abstract] NOT marginal[Title/Abstract] & Results \\
$\# 2$ & "gastric bypass"[Title/Abstract] AND perforation[Title/Abstract] NOT anastomosis[Title/Abstract] & 151 \\
$\# 3$ & "gastric bypass"[Title/Abstract]) AND "gastrointestinal bleeding”[Title/Abstract] NOT anastomosis[Title/Abstract] & 47 & 115 \\
$\# 4$ & "gastric bypass"[Title/Abstract]) AND "gastrointestinal hemorrhage"[Title/Abstract] NOT anastomosis[Title/Abstract] & 14 \\
\hline
\end{tabular}


Fig. 1 Flow diagram of study selection [29]

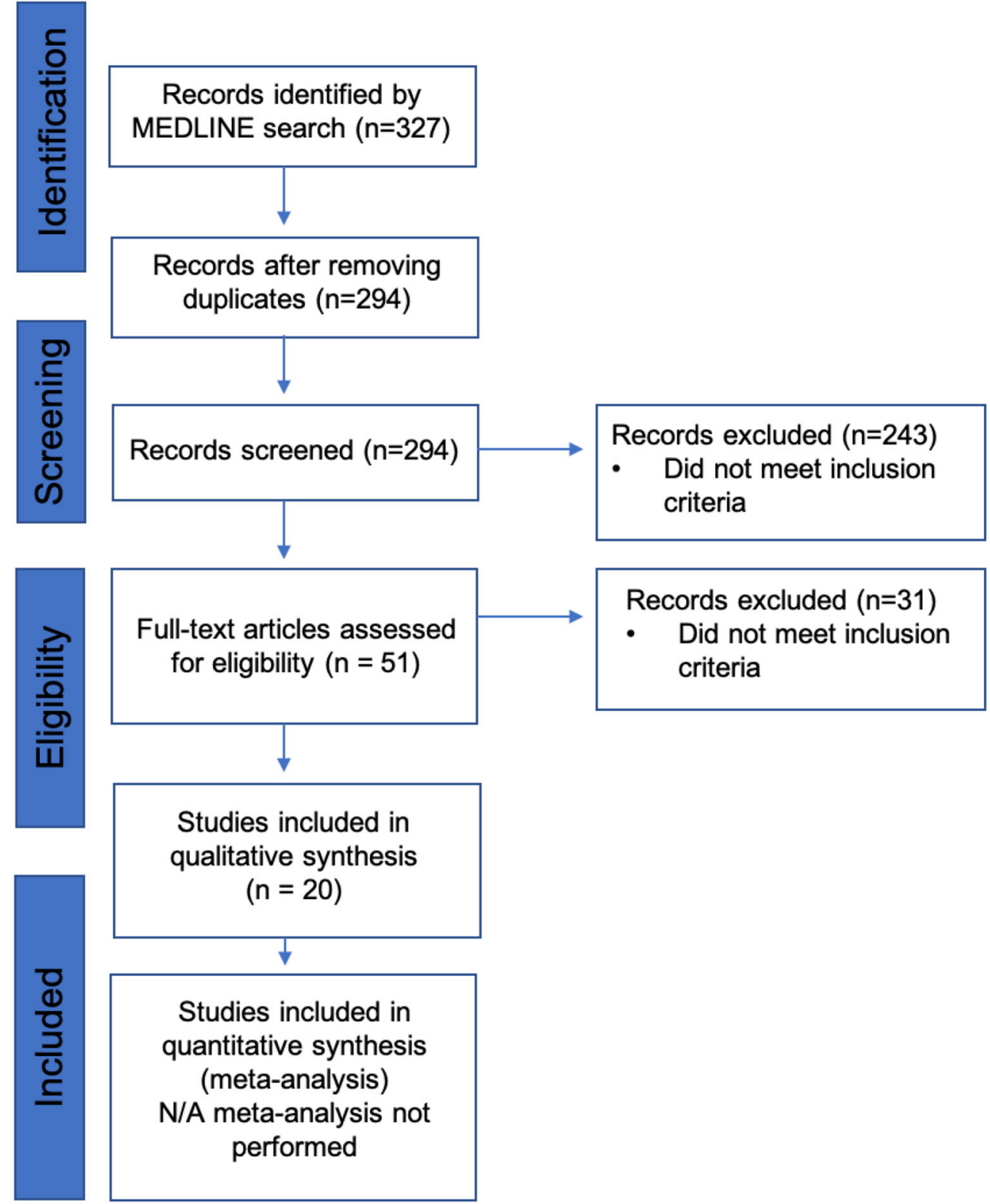

feedback [41]. RYGB results in altered gastric emptying, reduction in intestinal absorption surface, and a change in $\mathrm{pH}$. This leads to pharmacokinetic changes where PPIs, as lipophilic drugs, are absorbed to a lesser degree [42]. As PPIs are degraded by luminal acid, they are usually protected by a coating to prohibit premature activation and enable later absorption in the small bowel which again is altered. Likewise, opened PPI capsules have a significantly better effect on MU healing than intact capsules [43]. In line with these pharmacokinetic changes, plasma concentrations of omeprazole metabolites in patients after RYGB are significantly reduced compared to the corresponding levels in pre-RYGB and controls [30].
Other Risk Factors: NSAIDs, Smoking, H. pylori, and ZES

\section{Nonsteroidal Anti-inflammatory Drugs}

More than 30 million patients use NSAIDs on a daily basis [44]. As unselective inhibitors of the cyclo-oxygenase pathway, they deeply affect the gastric mucous barrier [44]. NSAID use is a risk factor for PUD in the general population and for MU after RYGB $[45,46]$. In the long term, up to $40 \%$ of NSAID users experience gastroduodenal ulcers [12].

In 40 of the 54 reported patients (74\%), NSAID use was stated. Surprisingly, only 6 of the 40 patients $(15 \%)$ had a history of NSAID use. Thus, other factors might have a higher impact on ulcer formation. 
Table 2 Patient characteristics and risk factors ( $Y$ yes, $N$ no, $n / a$ not available, NSAIDs non-steroidal anti-inflammatory drugs)

\begin{tabular}{|c|c|c|c|c|c|c|}
\hline \multirow[t]{2}{*}{ Author [Ref] } & \multicolumn{2}{|c|}{ Patient characteristics } & \multirow[b]{2}{*}{ Time since operation (years) } & \multirow[b]{2}{*}{ Smoking $(\mathrm{Y} / \mathrm{N})$} & \multicolumn{2}{|l|}{ Risk factors } \\
\hline & $\operatorname{Sex}(\mathrm{F} / \mathrm{M})$ & Age (years) & & & NSAIDs (Y/N) & H. pylori \\
\hline Andersen [7] & $1 / 0$ & 34 & 3 & $\mathrm{n} / \mathrm{a}$ & $\mathrm{N}$ & $\mathrm{n} / \mathrm{a}$ \\
\hline \multirow[t]{2}{*}{ Arshava [11] } & \multirow[t]{2}{*}{$0 / 2$} & 36 & 3 & $\mathrm{n} / \mathrm{a}$ & $\mathrm{Y}$ & $\mathrm{n} / \mathrm{a}$ \\
\hline & & 54 & 0.2 & $\mathrm{n} / \mathrm{a}$ & $\mathrm{n} / \mathrm{a}$ & $\mathrm{n} / \mathrm{a}$ \\
\hline Bjorkman [12] & $0 / 1$ & 24 & 6 & $\mathrm{n} / \mathrm{a}$ & $\mathrm{N}$ & $\mathrm{n} / \mathrm{a}$ \\
\hline \multirow[t]{3}{*}{ Braley [13] } & \multirow[t]{3}{*}{$2 / 1$} & 49 & 17 & $\mathrm{n} / \mathrm{a}$ & $\mathrm{n} / \mathrm{a}$ & $\mathrm{n} / \mathrm{a}$ \\
\hline & & 59 & 17 & $\mathrm{n} / \mathrm{a}$ & $\mathrm{n} / \mathrm{a}$ & $\mathrm{n} / \mathrm{a}$ \\
\hline & & 49 & 16 & $\mathrm{n} / \mathrm{a}$ & $\mathrm{n} / \mathrm{a}$ & $\mathrm{n} / \mathrm{a}$ \\
\hline Dai [9] & $1 / 0$ & 54 & 5 & $\mathrm{~N}$ & $\mathrm{~N}$ & neg \\
\hline Eid [14] & $0 / 1$ & 61 & 10 & $\mathrm{~N}$ & $\mathrm{~N}$ & $\mathrm{n} / \mathrm{a}$ \\
\hline Gypen [15] & $1 / 0$ & 35 & 0.2 & $\mathrm{n} / \mathrm{a}$ & $\mathrm{n} / \mathrm{a}$ & pos \\
\hline Husain [16] & $1 / 0$ & 63 & 1.5 & $\mathrm{n} / \mathrm{a}$ & $\mathrm{n} / \mathrm{a}$ & $\mathrm{n} / \mathrm{a}$ \\
\hline \multirow[t]{7}{*}{ Iranmannesh [28] } & \multirow[t]{7}{*}{$4 / 3$} & 48 & 20 & $\mathrm{n} / \mathrm{a}$ & $\mathrm{Y}$ & empirical eradication \\
\hline & & 39 & 10 & $\mathrm{n} / \mathrm{a}$ & $\mathrm{N}$ & empirical eradication \\
\hline & & 61 & 7 & $\mathrm{n} / \mathrm{a}$ & $\mathrm{N}$ & empirical eradication \\
\hline & & 54 & 10 & $\mathrm{n} / \mathrm{a}$ & $\mathrm{N}$ & empirical eradication \\
\hline & & 40 & 13 & $\mathrm{n} / \mathrm{a}$ & $\mathrm{N}$ & empirical eradication \\
\hline & & 70 & 9 & $\mathrm{n} / \mathrm{a}$ & $\mathrm{N}$ & empirical eradication \\
\hline & & 45 & 16 & $\mathrm{n} / \mathrm{a}$ & $\mathrm{Y}$ & empirical eradication \\
\hline \multirow[t]{2}{*}{ Iskandar [17] } & \multirow[t]{2}{*}{$0 / 2$} & 59 & 10 & $\mathrm{n} / \mathrm{a}$ & $\mathrm{N}$ & neg \\
\hline & & 37 & $\mathrm{n} / \mathrm{a}$ & $\mathrm{n} / \mathrm{a}$ & $\mathrm{N}$ & neg \\
\hline Issa [18] & $0 / 1$ & 39 & 1.2 & $\mathrm{n} / \mathrm{a}$ & $\mathrm{N}$ & pos \\
\hline Ivanecz [19] & $0 / 1$ & 59 & 2 & $\mathrm{~N}$ & $\mathrm{Y}$ & neg \\
\hline \multirow[t]{11}{*}{ Macgregor [20] } & \multirow[t]{11}{*}{$9 / 2$} & 63 & 1.9 & $\mathrm{n} / \mathrm{a}$ & $\mathrm{N}$ & $\mathrm{n} / \mathrm{a}$ \\
\hline & & 37 & 1.8 & $\mathrm{n} / \mathrm{a}$ & $\mathrm{N}$ & $\mathrm{n} / \mathrm{a}$ \\
\hline & & 40 & 8 & $\mathrm{n} / \mathrm{a}$ & $\mathrm{N}$ & $\mathrm{n} / \mathrm{a}$ \\
\hline & & 31 & 0.6 & $\mathrm{n} / \mathrm{a}$ & $\mathrm{N}$ & $\mathrm{n} / \mathrm{a}$ \\
\hline & & 53 & 5 & $\mathrm{n} / \mathrm{a}$ & $\mathrm{N}$ & $\mathrm{n} / \mathrm{a}$ \\
\hline & & 43 & 8 & $\mathrm{n} / \mathrm{a}$ & $\mathrm{N}$ & $\mathrm{n} / \mathrm{a}$ \\
\hline & & 29 & 11 & $\mathrm{n} / \mathrm{a}$ & $\mathrm{N}$ & $\mathrm{n} / \mathrm{a}$ \\
\hline & & 48 & 4 & $\mathrm{n} / \mathrm{a}$ & $\mathrm{N}$ & $\mathrm{n} / \mathrm{a}$ \\
\hline & & 57 & 1.5 & $\mathrm{n} / \mathrm{a}$ & $\mathrm{N}$ & $\mathrm{n} / \mathrm{a}$ \\
\hline & & 40 & 20 days & $\mathrm{n} / \mathrm{a}$ & $\mathrm{N}$ & $\mathrm{n} / \mathrm{a}$ \\
\hline & & 56 & 12 & $\mathrm{n} / \mathrm{a}$ & $\mathrm{N}$ & $\mathrm{n} / \mathrm{a}$ \\
\hline Mittermair [21] & $1 / 0$ & 54 & 1.3 & $\mathrm{n} / \mathrm{a}$ & $\mathrm{n} / \mathrm{a}$ & pos \\
\hline Ovaere [10] & $1 / 0$ & 33 & 1.2 & $\mathrm{~N}$ & $\mathrm{~N}$ & neg \\
\hline Papasavas [22] & $1 / 0$ & 35 & 1 & $\mathrm{n} / \mathrm{a}$ & $\mathrm{n} / \mathrm{a}$ & neg \\
\hline Patrascu [8] & $1 / 0$ & 52 & 7 & $\mathrm{~N}$ & $\mathrm{~N}$ & neg \\
\hline \multirow[t]{2}{*}{ Pohl [6] } & \multirow[t]{2}{*}{$2 / 0$} & 46 & 6 & $\mathrm{~N}$ & $\mathrm{~N}$ & neg \\
\hline & & 74 & 14 & $\mathrm{~N}$ & $\mathrm{~N}$ & neg \\
\hline \multirow[t]{2}{*}{ Sasse [26] } & \multirow[t]{2}{*}{$1 / 1$} & 55 & 1 & $\mathrm{n} / \mathrm{a}$ & $\mathrm{Y}$ & $\mathrm{n} / \mathrm{a}$ \\
\hline & & 47 & 3.5 & $\mathrm{n} / \mathrm{a}$ & $\mathrm{Y}$ & $\mathrm{n} / \mathrm{a}$ \\
\hline Snyder [23] & $4 / 2$ & $53-67$ & $1.5-6$ & $\mathrm{n} / \mathrm{a}$ & $\mathrm{N}$ & 1 pos; 2 neg; 3 n/a \\
\hline Spires [24] & $0 / 1$ & 48 & 4 & $\mathrm{n} / \mathrm{a}$ & $\mathrm{n} / \mathrm{a}$ & $\mathrm{n} / \mathrm{a}$ \\
\hline \multirow[t]{4}{*}{ Zagzag [27] } & \multirow[t]{4}{*}{$5 / 0$} & 57 & 5 & $\mathrm{n} / \mathrm{a}$ & $\mathrm{n} / \mathrm{a}$ & pos \\
\hline & & 54 & 12 & $\mathrm{n} / \mathrm{a}$ & $\mathrm{n} / \mathrm{a}$ & pos \\
\hline & & 53 & 9 & $\mathrm{n} / \mathrm{a}$ & $\mathrm{n} / \mathrm{a}$ & neg \\
\hline & & 47 & 0.7 & $\mathrm{n} / \mathrm{a}$ & $\mathrm{n} / \mathrm{a}$ & $\mathrm{n} / \mathrm{a}$ \\
\hline
\end{tabular}


Table 2 (continued)

\begin{tabular}{|c|c|c|c|c|c|c|}
\hline \multirow[t]{2}{*}{ Author [Ref] } & \multicolumn{2}{|c|}{ Patient characteristics } & \multirow[b]{2}{*}{ Time since operation (years) } & \multirow[b]{2}{*}{ Smoking $(\mathrm{Y} / \mathrm{N})$} & \multicolumn{2}{|l|}{ Risk factors } \\
\hline & $\operatorname{Sex}(\mathrm{F} / \mathrm{M})$ & Age (years) & & & NSAIDs $(\mathrm{Y} / \mathrm{N})$ & H. pylori \\
\hline & & 35 & 2 & $\mathrm{n} / \mathrm{a}$ & $\mathrm{n} / \mathrm{a}$ & neg \\
\hline Zerey [25] & $0 / 1$ & 57 & 12 & $\mathrm{~N}$ & $\mathrm{~N}$ & $\mathrm{n} / \mathrm{a}$ \\
\hline
\end{tabular}

\section{Smoking}

There is wide evidence implicating smoking as a risk factor for the occurrence, recurrence, and complications of PUD [47]. Suggested mechanisms include increased gastric acid secretion, altered gastric motility, a higher rate of duodenogastric reflux, and impaired duodenal and pancreatic bicarbonate secretion $[47,48]$. Among patients with RYGB, smoking seems to increase the risk for MU and especially perforation [49]. Furthermore, ulcer healing is impaired in smoking patients compared to non-smokers [49].

Smoking behavior was reported only for 8 patients (15\%), and none of them currently smoked.

\section{Helicobacter pylori}

HP (Helicobacter pylori) is one of the most common human infections and plays a pivotal role in the development of gastritis, ulcer formation, and malignant lesions [50-53]. Its prevalence in bariatric patients ranges up to $85 \%$, yet data are controversial and cover mostly MU [54]. Consequently, international guidelines differ in their recommendations for HP screening and management in bariatric patients $[55,56]$.

Detection of HP in post-RYGB patients can be challenging; histological samples remain the gold standard. Urea breath tests, especially in the absence of a pouch infection, can be falsely negative, as most of the gastric mucosa will not be in direct contact with urea [15]. Serology is of less diagnostic value since complete resolution of elevated $\operatorname{IgG}$ antibody titers after treatment of HP infection is not common, even though negative IgG antibodies can exclude HP [50,57]. With a sensitivity and specificity over $90 \%$, monoclonal stool antigen tests are probably the most suitable non-invasive diagnostic tool $[50,57]$.

Reported data provided the HP status for 20 of 54 patients $(37 \%)$. Based on histological findings, 7 (15\%) were positive. However, 7 more were eradicated empirically. Given the unknown influence of HP on the development of PUD after RYGB, its role as the most common proven risk factor for gastric cancer, and impaired access to the excluded stomach and duodenum for surveillance, patients should be screened preoperatively unless further data are available [55, 56]. Additionally, biopsies should be taken in revisional cases.
Zollinger-Ellison Syndrome (ZES)

ZES (Zollinger-Ellison syndrome) is a rare condition in which gastrin-secreting neuroendocrine tumors cause elevated acid production from gastric parietal cells, thus leading to recurrent peptic ulcers. Approximately $75 \%$ of ZES are sporadic, whereas $25 \%$ are associated with multiple endocrine neoplasm type 1 . There is a single case report of a patient with recurrent gastrojejunal anastomotic strictures and MU following RYGB due to a gastrinoma of the duodenum [58]. The role of ZES is negligible but should be considered in cases of multiple recurrent or refractory ulcers.

\section{Gastrointestinal Motility: Gastroparesis/Stasis}

Gastroparesis can occur following planned or inadvertent vagotomy [59]. Its incidence after partial gastrectomy is up to $5 \%$ [60]. Changes in ghrelin secretion influence gastric motility $[60,61]$. Bile reflux into the gastric remnant is observed in $36 \%$ of post-RYGB patients, and its deleterious effects on the mucosal barrier lead to chronic gastritis and intestinal metaplasia and may contribute to the formation of ulcers $[62,63]$.

Furthermore, delayed emptying and stasis in the biliopancreatic limb may predispose patients to bacterial overgrowth followed by inflammatory changes in the intestinal wall potentially leading to ulceration [64].

\section{Diagnosis}

\section{Incidence of Gastritis and Predictors of PUD}

Studies evaluating the gastric remnant after RYGB are rare. Among 53 patients with RYGB, remnant gastritis was found in $87 \%$ of patients with a normal mucosa in the pouch, indicating a harmful effect of unbuffered acid on the gastric remnant [31]. Elsewhere, in more than half of patients taking PPI, endoscopy of the gastric remnant revealed peptic changes [30].

Considering symptoms as surrogates for gastritis and PUD, upper abdominal pain by far is the most frequent symptom leading to readmissions after RYGB [65]. Of the reported 
Table 3 Presentation, treatment, and outcomes

\begin{tabular}{|c|c|c|c|c|c|c|}
\hline Author & $n$ & Presentation & Location & Treatment & Outcome & Follow-up \\
\hline Andersen [7] & 1 & Perforation & Gastric remnant & Ulcer excision, bypass take down & Cured & 9 days \\
\hline \multirow[t]{2}{*}{ Arshava [11] } & \multirow[t]{2}{*}{2} & Perforation & Gastric remnant & Remnant gastrectomy & Cured & 6 months \\
\hline & & Perforation & Gastric remnant & Remnant gastrectomy, pancreas preserving duodenal resection & Cured & $\mathrm{n} / \mathrm{a}$ \\
\hline Bjorkman [12] & 1 & Perforation & Duodenum & Remnant gastrectomy, duodenal stump oversewing & Cured & $\mathrm{n} / \mathrm{a}$ \\
\hline \multirow[t]{3}{*}{ Braley [13] } & \multirow[t]{3}{*}{3} & Bleeding & Duodenum & Remnant gastrectomy, resection of first portion of duodenum & Cured & 24 months \\
\hline & & Bleeding & Gastric remnant & Remnant gastrectomy & Cured & 12 months \\
\hline & & Bleeding & Gastric remnant & Remnant gastrectomy & Cured & 9 months \\
\hline Dai [9] & 1 & Perforation & Gastric remnant & Oversewing, omental patch, gastric tube placement & Cured & 4 weeks \\
\hline Eid [14] & 1 & Bleeding & $\mathrm{n} / \mathrm{a}$ & Angiography, coiling & Cured & $\mathrm{n} / \mathrm{a}$ \\
\hline Gypen [15] & 1 & Perforation & Duodenum & Oversewing, omental patch & Cured & 6 months \\
\hline Husain [16] & 1 & Bleeding & Duodenum & Remnant gastrectomy, resection of first portion of duodenum & Cured & $\mathrm{n} / \mathrm{a}$ \\
\hline \multirow[t]{7}{*}{ Irannmanesh [28] } & \multirow[t]{7}{*}{7} & Perforation & Gastric remnant & Oversewing, omental patch & Cured & 12 days \\
\hline & & Perforation & Gastric remnant & Oversewing, omental patch & Cured & 3 days \\
\hline & & Perforation & Gastric remnant & Oversewing, omental patch, gastrostomy & Cured & 8 dyas \\
\hline & & Necrosis & Gastric remnant & Remnant gastrectomy & Cured & 8 days \\
\hline & & Bleeding & Gastric remnant & Enteroscopy with local hemostasis & Cured & 5 days \\
\hline & & Bleeding & Gastric remnant & conservative & Cured & 3 days \\
\hline & & Bleeding & Gastric remnant & Enteroscopy with local hemostasis & Cured & 3 days \\
\hline \multirow[t]{2}{*}{ Iskandar [17] } & \multirow[t]{2}{*}{2} & Perforation & Duodenum & Oversewing & Cured & 1 week \\
\hline & & Perforation & Duodenum & Duodenostomy, drainage & Cured & $\mathrm{n} / \mathrm{a}$ \\
\hline Issa [18] & 1 & Bleeding & Duodenum & Laparoscopic gastroduodenoscopy, electrocoagulation & Cured & 10 months \\
\hline Ivanecz [19] & 1 & Bleeding & Duodenum & Remnant gastrectomy, resection of first portion of duodenum & Cured & 3 months \\
\hline \multirow[t]{11}{*}{ Macgregor [20] } & \multirow[t]{11}{*}{11} & Perforation & Duodenum & Oversewing, subsequent remnant gastrectomy & Cured & $\mathrm{n} / \mathrm{a}$ \\
\hline & & Perforation & Gastric remnant & Oversewing and gastrotomy, subsequent remnant gastrectomy & Cured & $\mathrm{n} / \mathrm{a}$ \\
\hline & & Perforation & Duodenum & Oversewing & Cured & $\mathrm{n} / \mathrm{a}$ \\
\hline & & Perforation & Duodenum & Oversewing, and gastrotomy, subsequent remnant gastrectomy & Cured & $\mathrm{n} / \mathrm{a}$ \\
\hline & & Perforation & Duodenum & Oversewing, vagotomy, pyloroplasty & Cured & $\mathrm{n} / \mathrm{a}$ \\
\hline & & Perforation & Duodenum & Oversewing, subsequent remnant gastrectomy & Cured & $\mathrm{n} / \mathrm{a}$ \\
\hline & & Perforation & Duodenum & Oversewing, subsequent remnant gastrectomy & Cured & $\mathrm{n} / \mathrm{a}$ \\
\hline & & Perforation & Duodenum & Oversewing, subsequent remnant gastrectomy & Cured & $\mathrm{n} / \mathrm{a}$ \\
\hline & & Perforation & Gastric remnant, & Oversewing, subsequent remnant gastrectomy & Cured & $\mathrm{n} / \mathrm{a}$ \\
\hline & & Perforation & Duodenum & Oversewing, subsequent remnant gastrectomy & Cured & $\mathrm{n} / \mathrm{a}$ \\
\hline & & Perforation & Duodenum & Gastrostomy, subsequent remnant gastrectomy & Cured & $\mathrm{n} / \mathrm{a}$ \\
\hline Mittermair [21] & 1 & Perforation & Duodenum & Oversewing & Cured & 6 days \\
\hline Ovaere [10] & & Perforation & Gastric remnant & Oversewing, omental patch & Cured & $\mathrm{n} / \mathrm{a}$ \\
\hline Papasavas [22] & 1 & Perforation & Gastric remnant & Remnant gastrectomy & Cured & 38 months \\
\hline Patrascu $[8]$ & & Bleeding & Gastric remnant & Remnant gastrectomy & Cured & 2 months \\
\hline \multirow[t]{2}{*}{ Pohl [6] } & \multirow[t]{2}{*}{2} & Perforation & Duodenum & Oversewing, omental patch & Cured & 3 years \\
\hline & & Perforation & Duodenum & Oversewing, omental patch & Cured & 3 years \\
\hline \multirow[t]{2}{*}{ Sasse [26] } & \multirow[t]{2}{*}{2} & Perforation & Gastric remnant & Oversewing, omental patch & Cured & 2 years \\
\hline & & Perforation & Gastric remnant & Intraoperative death & Death & \\
\hline \multirow[t]{2}{*}{ Snyder [23] } & \multirow[t]{2}{*}{6} & 4 perforation & 4 duodenum & 5 remnant gastrectomy & 5 Cured & $2-4$ years \\
\hline & & 2 Bleeding & 2 Gastric remnant & 1 duodenal oversewing & 1 Death & \\
\hline Spires [24] & 1 & Bleeding & Duodenum & Remnant gastrectomy & Cured & 6 months \\
\hline \multirow[t]{5}{*}{ Zagzag [27] } & \multirow[t]{5}{*}{5} & Perforation & Duodenum & Graham patch & Cured & $\mathrm{n} / \mathrm{a}$ \\
\hline & & Perforation & Duodenum & Graham patch & Cured & $\mathrm{n} / \mathrm{a}$ \\
\hline & & Perforation & Duodenum & Graham patch & Cured & $\mathrm{n} / \mathrm{a}$ \\
\hline & & Perforation & Duodenum & Graham patch & Cured & $\mathrm{n} / \mathrm{a}$ \\
\hline & & Perforation & Duodenum & Graham patch & Cured & $\mathrm{n} / \mathrm{a}$ \\
\hline
\end{tabular}


Table 3 (continued)

\begin{tabular}{|c|c|c|c|c|c|c|}
\hline Author & $n$ & Presentation & Location & Treatment & Outcome & Follow-up \\
\hline Zerey [25] & 1 & Bleeding & Duodenum & Duodenotomy, oversewing & Cured & 5 days \\
\hline
\end{tabular}

patients, over two-thirds reported epigastric and/or upper abdominal pain.

\section{Free Air: Plain X-ray and Abdominal CT}

With a sensitivity of approximately $86 \%$ in detecting gastrointestinal perforation, CT is widely accepted as accurate in the evaluation of such patients [66]. However, in post-RYGB patients, the presence of free intra-abdominal air due to perforation of the excluded segments is much less common if not absent. Patients with perforation had plain X-rays in 20 of 41 cases $(49 \%)$, and free air was detected in two patients. When performed, $44 \%$ of CT scans showed free intra-abdominal air. Thus, in patients after RYGB, negative CT findings do not exclude a viscus perforation, and operative exploration should be performed with a low threshold. Indeed, the presence of free air and even more fluid should raise suspicions about a pouch-gastric fistula or irregularities at the level of the jejunojejunal anastomosis $[6,15,20,67]$.

\section{Bleeding: CT and Mesenteric Angiography}

The sensitivity and specificity of CT angiography for active gastrointestinal bleeding are over $90 \%$. However, its sensitivity for obscure bleeding is only approximately $45 \%$ [68]. Even though it lacks therapeutic options, CT angiography provides essential information regarding the bleeding origin and allows for subsequent mesenteric angiography to be targeted to an area of interest leading to an improved angiographic detection rate. The technical success rate of transarterial embolization in gastrointestinal bleeding is reported to be up to $93 \%$ with a rate of bleeding cessation up to $81 \%$ [69].

Among the reported cases of ulcer bleeding following RYGB, only indirect signs but no active bleeding were detected. Mesenteric angiography without previous CT angiography was performed in $25 \%$ of patients, and angiography showed active bleeding in $67 \%$ of patients. One patient had successful embolization, whereas embolization failed in the other patient, and surgical intervention was needed to control bleeding [14, 25].

Transarterial angiography with subsequent embolization is an option to address bleeding in those patients. This procedure is noninvasive and has a high success rate [69]. However, in a general context, it might be more purposeful to address such patients surgically, or rather endoscopically via temporary gastrostomy.

\section{Access to the Excluded Segments: Double-Balloon Endoscopy, Intraoperative Temporary Gastrostomy, and Pouch Gastrostomy}

There are various ways to access the excluded segments postRYGB. Upper endoscopy is considered a first-line approach for the diagnosis and treatment of upper gastrointestinal bleeding and provides a valid alternative in the treatment of postbariatric complications such as leaks or anastomotic bleeding [70]. Whereas gastro-jejunal anastomoses can easily be evaluated, the combined length of alimentary and biliopancreatic limbs complicates access to the gastric remnants and duodenums. With the use of a pediatric colonoscope, the remnant can be reached in up to $68 \%$ of cases [31]. This rate can be raised to $88 \%$ by applying a double-balloon technique albeit with a higher perforation rate of $10 \%$ [71].

Eleven $(20 \%)$ of the reported patients underwent a standard upper endoscopy, which was non-diagnostic in every case. In 5 patients, retrograde endoscopy was attempted; the remnant was reached in three patients, and treatment of the bleeding was successful in two patients $[12,14,22,28]$. Thus, in time-critical situations, conventional upper endoscopy can rule out pathologies of the gastric pouch, anastomosis, and alimentary limb, but its diagnostic value in assessing the excluded segments is limited.

Access to the excluded segments can further be achieved with percutaneous transgastric endoscopy. CT or ultrasonographic guidance to introduce a guidewire is followed by placement of a gastrostomy tube into the remnant stomach. Serial dilations of the gastrostomy over several weeks are then required until an endoscope can be introduced. This technique is safe and effective but obviously not suitable for emergency situations [4, 5, 62].

Intraoperative transgastric endoscopy allows for addressing or excluding other pathologies at the same time [72]. Usually, access to the gastric remnant is established during laparoscopy via temporary remnant gastrostomy [72]. Among the reviewed patients with ulcer bleeding or perforation after RYGB, 8 of 54 had (15\%) intraoperative transgastric endoscopy $[13,18,25,28]$. Endoscopy revealed duodenal ulcers in 3 cases and gastritis and benign ulcers in 2 cases.

\section{Treatment and Follow-Up}

There are various options to address complicated PUDs. The main goal is to resolve septic foci and provide a 
solution for future follow-up in this special anatomic situation at the same time.

\section{Gastrectomy Versus Oversewing Ulcers}

As patients with PUD after RYGB are more likely to be diagnosed with complicated PUD, the treatment is generally operative. There are several controversial issues, such as whether to perform remnant gastrectomy, ulcer repair with concomitant vagotomy, or mandatory intraoperative gastroscopy. In the case of free air or fluid, assessing the patency of the jejuno-jejunostomy is mandatory [67].

The recurrence rate of PUD determines the extent of surgery needed. So far, the paucity of data and the rather short follow-up overall do not allow for general recommendations. Although remnant gastrectomy seems drastic, it certainly facilitates the follow-up and most effectively counteracts PUD unless there is ectopic gastric tissue elsewhere. In the case of perforated PUD, oversewing after biopsies is an option. It is certainly advisable to enable easier future access to the remnant stomach, especially when intraoperative gastroscopy is not performed at the time of the procedure. (Super)selective vagotomy may be added to reduce acid production.

Of 54 described cases, 50 (93\%) underwent surgery. In $48 \%$ of these patients, remnant gastrectomy was performed, combined with resection of the first portion of the duodenum in $6 \%$ and pancreas-preserving duodenal resection in $2 \%$. Oversewing or Graham patches were performed in $37 \%$ of patients. Other procedures included ulcer excision with bypass reversal, duodenostomy with drainage, coagulation by intraoperative endoscopy, and angiographic coiling (tbl 2).

In a short-term follow-up, 94\% of patients were cured, one needed reoperation because of early postoperative bleeding following remnant gastrectomy with resection of the first part of the duodenum, and two patients died, one from pulmonary complications and the other one intraoperatively due to multiorgan failure.

There is a wide variety in the duration of follow-up, ranging from 5 days to 4 years and only limited data are available overall.

\section{Follow-Up: Secondary Prophylaxis, Cancer Risk}

Postoperative eradication of HP was routine for positive patients. Secondary prophylaxis with PPIs was initiated in 23 of 54 patients (of whom one had a remnant gastrectomy), with varying durations, from 2 weeks to lifelong. Meta-analytic data suggest a significant benefit of prophylactic PPI in reducing MU after RYGB [73]. Despite lacking evidence, PPI may therefore be considered to counteract recurrent PUD in the excluded segments.
Cancer in the remnant stomach is rare; a meta-analysis found 17 patients who reported with pain, abdominal distension, and weight loss as main symptoms [74].

\section{Conclusion}

PUD in the excluded segments post-RYGB is rare but lifethreatening. The presentation of perforated PUD is different from that in non-bariatric patients, as the usual signs, such as free air, may not be present. Access to the excluded segments is impaired; in time-critical situations, temporary gastrostomy during laparoscopy is a viable option. Remnant gastrectomy is a definitive solution that forgoes the need for further endoscopic follow-up. Scarce available data do not allow for any conclusion about the role of potential risk factors; however, HP should be eradicated. Secondary prophylaxis with PPI should be administered in increased dosage due to altered absorption post-RYGB.

Funding Open access funding provided by University of Bern.

\section{Compliance with Ethical Standards}

Conflict of Interest The authors declare that they have no conflict of interest.

Ethical Approval For this type of study, formal consent is not required.

Informed Consent Informed consent does not apply.

Open Access This article is licensed under a Creative Commons Attribution 4.0 International License, which permits use, sharing, adaptation, distribution and reproduction in any medium or format, as long as you give appropriate credit to the original author(s) and the source, provide a link to the Creative Commons licence, and indicate if changes were made. The images or other third party material in this article are included in the article's Creative Commons licence, unless indicated otherwise in a credit line to the material. If material is not included in the article's Creative Commons licence and your intended use is not permitted by statutory regulation or exceeds the permitted use, you will need to obtain permission directly from the copyright holder. To view a copy of this licence, visit http://creativecommons.org/licenses/by/4.0/.

\section{References}

1. Angrisani L, Santonicola A, Iovino P, et al. Bariatric surgery and endoluminal procedures: IFSO worldwide survey 2014. Obes Surg. 2017;27(9):2279-89.

2. Schauer PR, Bhatt DL, Kirwan JP, et al. Bariatric surgery versus intensive medical therapy for diabetes - 5-year outcomes. N Engl J Med. 2017;376(7):641-51.

3. Nguyen NT, Varela JE. Bariatric surgery for obesity and metabolic disorders: state of the art. Nat Rev Gastroenterol Hepatol. 2017;14(3):160-9. 
4. Ahmed AR, Husain S, Saad N, et al. Accessing the common bile duct after Roux-en-Y gastric bypass. Surg Obes Relat Dis. 2007;3(6):640-3.

5. Martinez J, Guerrero L, Byers P, et al. Endoscopic retrograde cholangiopancreatography and gastroduodenoscopy after Rouxen-Y gastric bypass. Surg Endosc. 2006;20(10):1548-50.

6. Pohl D et al. Perforated duodenal ulcers after Roux-Y gastric bypass. Am J Emerg Med. 2018;36(8):1525.e1-3.

7. Andersen OS, Paine GT, Morse EK. An unusual complication of gastric bypass: perforated antral ulcer. Am J Gastroenterol. 1982;77(2):93-4.

8. Patrascu S, Ponz CB, Ananin SF, et al. A delayed acute complication of bariatric surgery: gastric remnant haemorrhagic ulcer after Roux-en-Y gastric bypass. J Minim Access Surg. 2018;14(1):68 70.

9. Dai L, Shah MM, Rosenblatt S. Perforated gastric remnant ulcer after laparoscopic gastric bypass. BMJ Case Rep. 2018;2018: bcr2017222190. https://doi.org/10.1136/bcr-2017-222190.

10. Ovaere S, Tse WH, Schipper EE, Spanjersberg WR. Perforation of the gastric remnant in a patient post-Roux-en-Y gastric bypass. BMJ Case Rep. 2016;2016:bcr2015213862. https://doi.org/10. 1136/bcr-2015-213862.

11. Arshava EV, Mitchell C, Thomsen T, et al. Delayed perforation of the defunctionalized stomach after Roux-en-Y gastric bypass surgery. Surg Obes Relat Dis. 2006;2(4):472-6. discussion 476-7

12. Bjorkman DJ, Alexander JR, Simons MA. Perforated duodenal ulcer after gastric bypass surgery. Am J Gastroenterol. 1989;84(2):170-2.

13. Braley SC, Nguyen NT, Wolfe BM. Late gastrointestinal hemorrhage after gastric bypass. Obes Surg. 2002;12(3):404-7.

14. Eid JJ, Radecke JM, Murr MM. Gastrointestinal bleeding from the excluded stomach: a proposed algorithmic approach to management. Surg Obes Relat Dis. 2015;11(1):e11-4.

15. Gypen BJ, Hubens GJA, Hartman V, et al. Perforated duodenal ulcer after laparoscopic gastric bypass. Obes Surg. 2008;18(12): 1644-6.

16. Husain S, Ahmed AR, Johnson J, et al. CT scan diagnosis of bleeding peptic ulcer after gastric bypass. Obes Surg. 2007;17(11):1520 2.

17. Iskandar ME et al. Diagnosis and management of perforated duodenal ulcers following Roux-en-Y gastric bypass: a report of two cases and a review of the literature. Case Rep Surg. 2015;2015: 353468.

18. Issa $\mathrm{H}$, al-Saif $\mathrm{O}$, al-Momen $\mathrm{S}$, et al. Bleeding duodenal ulcer after Roux-en-Y gastric bypass surgery: the value of laparoscopic gastroduodenoscopy. Ann Saudi Med. 2010;30(1):67-9.

19. Ivanecz A, Sremec M, Ceranić D, et al. Life threatening bleeding from duodenal ulcer after Roux-en-Y gastric bypass: case report and review of the literature. World J Gastrointest Endosc. 2014;6(12):625-9.

20. Macgregor AM, Pickens NE, Thoburn EK. Perforated peptic ulcer following gastric bypass for obesity. Am Surg. 1999;65(3):222-5.

21. Mittermair R, Renz O. An unusual complication of gastric bypass: perforated duodenal ulcer. Obes Surg. 2007;17(5):701-3.

22. Papasavas PK, Yeaney WW, Caushaj PF, et al. Perforation in the bypassed stomach following laparoscopic Roux-en-Y gastric bypass. Obes Surg. 2003;13(5):797-9.

23. Snyder JM. Peptic ulcer following gastric bypass. Obes Surg. 2007;17(10):1419.

24. Spires WV, Morris DM. Bleeding duodenal ulcer after gastric bypass procedure for obesity. South Med J. 1987;80(10):1325-6.

25. Zerey M, Sigmon LB, Kuwada TS, et al. Bleeding duodenal ulcer after Roux-en-Y gastric bypass surgery. J Am Osteopath Assoc. 2008;108(1):25-7.
26. Sasse KC, Ganser J, Kozar M, et al. Seven cases of gastric perforation in Roux-en-Y gastric bypass patients: what lessons can we learn? Obes Surg. 2008;18(5):530-4.

27. Zagzag J, Cohen NA, Fielding G, et al. Lack of diagnosis of pneumoperitoneum in perforated duodenal ulcer after RYGB: a short case series and review of the literature. Obes Surg. 2018;28(9): 2976-8.

28. Iranmanesh P, Manisundaran NV, Bajwa KS, et al. Management of acute gastric remnant complications after Roux-en-Y gastric bypass: a single-center case series. Obes Surg. 2020;30(7):2637-41.

29. Liberati A, Altman DG, Tetzlaff J, et al. The PRISMA statement for reporting systematic reviews and meta-analyses of studies that evaluate healthcare interventions: explanation and elaboration. BMJ. 2009;339:b2700.

30. Collares-Pelizaro RVA, Santos JS, Nonino CB, et al. Omeprazole absorption and fasting gastrinemia after roux-en-Y gastric bypass Obes Surg. 2017;27(9):2303-7.

31. Flickinger EG, Sinar DR, Pories WJ, et al. The bypassed stomach. Am J Surg. 1985;149(1):151-6.

32. Mason EE, Munns JR, Kealey GP, et al. Effect of gastric bypass on gastric secretion. Am J Surg. 1976;131(2):162-8.

33. Bass J, Freeman JB. Complications of gastric partitioning for morbid obesity. Adv Surg. 1984;18:223-55.

34. Capella JF, Capella RF. Staple disruption and marginal ulceration in gastric bypass procedures for weight reduction. Obes Surg. 1996;6(1):44-9.

35. Siilin $\mathrm{H}$, Wanders $\mathrm{A}$, Gustavsson $\mathrm{S}$, et al. The proximal gastric pouch invariably contains acid-producing parietal cells in Rouxen-Y gastric bypass. Obes Surg. 2005;15(6):771-7.

36. Meek CL, Lewis HB, Reimann F, et al. The effect of bariatric surgery on gastrointestinal and pancreatic peptide hormones. Peptides. 2016;77:28-37.

37. Zavros Y, Rieder G, Ferguson A, et al. Genetic or chemical hypochlorhydria is associated with inflammation that modulates parietal and G-cell populations in mice. Gastroenterology. 2002;122(1):119-33.

38. Borbely $Y$ et al. Exocrine pancreatic insufficiency after Roux-en-Y gastric bypass. Surg Obes Relat Dis. 2016;12(4):790-4.

39. Varban OA, Hawasli AA, Carlin AM, et al. Variation in utilization of acid-reducing medication at 1 year following bariatric surgery: results from the Michigan Bariatric Surgery Collaborative. Surg Obes Relat Dis. 2015;11(1):222-8.

40. Thereaux J, Lesuffleur T, Czernichow S, et al. Do sleeve gastrectomy and gastric bypass influence treatment with proton pump inhibitors 4 years after surgery? A nationwide cohort. Surg Obes Relat Dis. 2017;13(6):951-9.

41. Schubert ML. Gastric secretion. Curr Opin Gastroenterol. 2010;26(6):598-603.

42. Padwal R, Brocks D, Sharma AM. A systematic review of drug absorption following bariatric surgery and its theoretical implications. Obes Rev. 2010;11(1):41-50.

43. Schulman AR, Chan WW, Devery A, et al. Opened proton pump inhibitor capsules reduce time to healing compared with intact capsules for marginal ulceration following Roux-en-Y gastric bypass. Clin Gastroenterol Hepatol. 2017;15(4):494-500. e1

44. Bjarnason I, Scarpignato C, Holmgren E, Olszewski M, Rainsford $\mathrm{KD}$, Lanas A. Mechanisms of damage to the gastrointestinal tract from nonsteroidal anti-inflammatory drugs. Gastroenterology. 2018;154(3):500-14. https://doi.org/10.1053/j.gastro.2017.10.049.

45. Coblijn UK, Goucham AB, Lagarde SM, et al. Development of ulcer disease after Roux-en-Y gastric bypass, incidence, risk factors, and patient presentation: a systematic review. Obes Surg. 2014;24(2):299-309.

46. Huang JQ, Sridhar S, Hunt RH. Role of Helicobacter pylori infection and non-steroidal anti-inflammatory drugs in peptic-ulcer disease: a meta-analysis. Lancet. 2002;359(9300):14-22. 
47. Maity P, Biswas K, Roy S, et al. Smoking and the pathogenesis of gastroduodenal ulcer-recent mechanistic update. Mol Cell Biochem. 2003;253(1-2):329-38.

48. Li LF et al. Cigarette smoking and gastrointestinal diseases: the causal relationship and underlying molecular mechanisms (review). Int J Mol Med. 2014;34(2):372-80.

49. Azagury DE et al. Marginal ulceration after Roux-en-Y gastric bypass surgery: characteristics, risk factors, treatment, and outcomes. Endoscopy. 2011;43(11):950-4.

50. Carabotti M, D'Ercole C, Iossa A, et al. Helicobacter pylori infection in obesity and its clinical outcome after bariatric surgery. World J Gastroenterol. 2014;20(3):647-53.

51. Eslick GD, Lim LLY, Byles JE, et al. Association of Helicobacter pylori infection with gastric carcinoma: a meta-analysis. Am J Gastroenterol. 1999;94(9):2373-9.

52. Group, H.a.C.C. Gastric cancer and Helicobacter pylori: a combined analysis of 12 case control studies nested within prospective cohorts. Gut. 2001;49(3):347-53.

53. Mitchell H, Katelaris P. Epidemiology, clinical impacts and current clinical management of Helicobacter pylori infection. Med J Aust. 2016;204(10):376-80

54. Schulman AR, Abougergi MS, Thompson CC. H. pylori as a predictor of marginal ulceration: a nationwide analysis. Obesity (Silver Spring). 2017;25(3):522-6.

55. Fried $\mathrm{M}$ et al. Interdisciplinary European guidelines on metabolic and bariatric surgery. Obes Surg. 2014;24(1):42-55.

56. Mechanick JI et al. Clinical practice guidelines for the perioperative nutritional, metabolic, and nonsurgical support of the bariatric surgery patient-2013 update: cosponsored by American Association of Clinical Endocrinologists, the Obesity Society, and American Society for Metabolic \& Bariatric Surgery. Obesity (Silver Spring). 2013;21(Suppl 1):S1-27.

57. Malfertheiner P, Megraud F, O'Morain CA, et al. Management of Helicobacter pylori infection-the Maastricht IV/Florence consensus report. Gut. 2012;61(5):646-64.

58. Court I, Zissman P, Rosenthal RJ. Diagnosis and treatment of Zollinger Ellison syndrome in a morbidly obese patient after Roux-en-Y gastric bypass. Surg Obes Relat Dis. 2010;6(6):714-7.

59. van Wezenbeek MR, van Oudheusden TR, Smulders JF, et al. Transection versus preservation of the neurovascular bundle of the lesser omentum in primary Roux-en-Y gastric bypass surgery. Surg Obes Relat Dis. 2016;12(2):283-9.

60. Salameh JR, Schmieg Jr RE, Runnels JM, et al. Refractory gastroparesis after Roux-en-Y gastric bypass: surgical treatment with implantable pacemaker. J Gastrointest Surg. 2007;11(12): 1669-72.

61. Suzuki S, Ramos EJB, Goncalves CG, et al. Changes in GI hormones and their effect on gastric emptying and transit times after
Roux-en-Y gastric bypass in rat model. Surgery. 2005;138(2):28390.

62. Sundbom M, Nyman R, Hedenström H, et al. Investigation of the excluded stomach after Roux-en-Y gastric bypass. Obes Surg. 2001;11(1):25-7.

63. Vella E, Hovorka Z, Yarbrough DE, McQuitty E. Bile reflux of the remnant stomach following Roux-en-Y gastric bypass: an etiology of chronic abdominal pain treated with remnant gastrectomy. Surg Obes Relat Dis. 2017;13(8):1278-83. https://doi.org/10.1016/j. soard.2017.04.007.

64. Kroll D, Kohler A, Nett PC. What causes late perforation of the jejuno-jejunal anastomosis after Roux-en-Y gastric bypass surgery? Obes Surg. 2015;25(12):2421-2.

65. Greenstein AJ, O'Rourke RW. Abdominal pain after gastric bypass: suspects and solutions. Am J Surg. 2011;201(6):819-27.

66. Del Gaizo AJ et al. From esophagus to rectum: a comprehensive review of alimentary tract perforations at computed tomography. Abdom Imaging. 2014;39(4):802-23.

67. Daster S, Borbely Y, Peterli R. Acute pancreatitis after Roux-en-Y gastric bypass surgery due to reflux into biliopancreatic limb. Surg Obes Relat Dis. 2012;8(3):e37-9.

68. Wu LM, Xu JR, Yin Y, et al. Usefulness of CT angiography in diagnosing acute gastrointestinal bleeding: a meta-analysis. World $\mathrm{J}$ Gastroenterol. 2010;16(31):3957-63.

69. Loffroy R, Guiu B. Role of transcatheter arterial embolization for massive bleeding from gastroduodenal ulcers. World J Gastroenterol. 2009;15(47):5889-97.

70. Eisendrath P, Deviere J. Major complications of bariatric surgery: endoscopy as first-line treatment. Nat Rev Gastroenterol Hepatol. 2015;12(12):701-10.

71. Sakai P, Kuga R, Safatle-Ribeiro AV, et al. Is it feasible to reach the bypassed stomach after Roux-en-Y gastric bypass for morbid obesity? The use of the double-balloon enteroscope. Endoscopy. 2005;37(6):566-9.

72. Banerjee N, Parepally M, Byrne TK, et al. Systematic review of transgastric ERCP in Roux-en-Y gastric bypass patients. Surg Obes Relat Dis. 2017;13(7):1236-42.

73. Ying VW et al. Prophylactic PPI help reduce marginal ulcers after gastric bypass surgery: a systematic review and meta-analysis of cohort studies. Surg Endosc. 2015;29(5):1018-23.

74. Tornese S, Aiolfi A, Bonitta G, et al. Remnant gastric Cancer after Roux-en-Y gastric bypass: narrative review of the literature. Obes Surg. 2019;29(8):2609-13.

Publisher's Note Springer Nature remains neutral with regard to jurisdictional claims in published maps and institutional affiliations. 